\title{
THE WINTER RYE BREEDING AND GENETICS LABORATORYS FORMATION AND ACTIVITY IN PLANT PRODUCTION INSTITUTE ND. BY V. YA. YURIEV NAAS (REVIEW)
}

Yegorov D.K., Zmiievska O.A.

Plant Production Institute nd. by V.Ya. Yuriev NAAS

The main formation stages of winter rye breeding and genetics laboratory at Plant Production Institute nd. by V.Ya. Yuriev NAAS, the directions and results of its activity are given in the review article.

Key words: winter rye, Plant Production Institute, laboratory, varieties, hybrids, breeding

Plant Production Institute nd. by V.Ya. Yuriev NAAS in 2018 celebrates anniversary 110 years from the date of its foundation. The research on the direction of breeding 10 crops has been started since 1908. Each institute division made an essential contribution to development of Institute by theoretical and practical practices and has the history of becoming. Authors suggest readers to get acquainted with the main milestones of a becoming of winter rye breeding and genetics laboratory and its activity.

Directions and results of researches at the period of 1911-1963. Breeding work with winter rye at Plant Production Institute nd. by V.Ya. Yuriev NAAS (at that time at the Kharkiv selection station) was begun in 1911, when there were no developed breeding methods and strain testing technique yet. Development of methods occurred at the same time with the beginning of breeding work at the station. In the first years of scientific research samples of local varieties were collected. The first collecting was carried out in 1914, the second - in 1923 [1]. In 1930 the station used the material, collected by Ukrainian Plant Production Institute, for studying. In total 3064 samples, including collected samples in the Kharkiv region -1511 , in other regions of Ukraine -1433 , in the regions of the USSR -60 , foreign -60 , were studied. In process of their studying at first the main attention was concentrated on a local rye Nemyshlyanskaya, which was sown in the village Nemyshlya, located next to station, and then on the variety Petkuskaya. In 1923 scientists received the variety Nemyshlyanskaya 953 (authors A.F. Gelmer, B.K. Enken, A.V. Chernysheva), created by method of mass selection from a rye Nemyshlyanskaya. On the signs the variety was the typical local varieties representative of steppe group, different in high winter hardiness and stable productivity even in adverse conditions. In due time creations of Nemyshlyanskaya 953 became the known success in rye breeding. But subsequently Nemyshlyanskaya 953 could not compete with more productive varieties and it was replaced with the variety Kharkovskaya 194 (authors M. Linnik, M.I. Smirnitsky, M.V. Lyaskovsky).

From 1938 to 1967 researches on breeding and primary seed farming of a rye winter were conducted by the breeder, the candidate of agricultural sciences V.P. Pakhomova [2].

At the recovery of breeding and seed-growing work with the variety after liberation of Kharkiv from the German invaders in 1943 it was carried out the selection of ears from an unknown reproduction of the variety Kharkovskaya 194, which accidentally remained in experemental farm, and at the station also it was used the material, which passed cruel freezing in 1939, and the one, returned from evacuation. On the basis of this material they were created primary links of seed farming with annual using of the seeds, grown up in different geographical areas, for repollination. As a result of work it was increased the flexibility of the variety Kharkovskaya 194, that allowed to expand considerably an introduction area of the variety and to zone it in 34 regions with acreage more than 1 million ha.

(C) D.K. Yegorov, O.A. Zmiievska. 2018.

ISSN 1026-9959. Селекція і насінництво. 2018. Випуск 113. 
In 1948 the research on creation of rye variety with a stem, rather short and steady against drowning, was started. For this purpose it was carried out the selection from the variety Kharkovskaya 194 [2]. At the end a new variety Kharkovskaya 55 was created (authors V.Ya. Yuryev, V.P. Pakhomova, B. Kononenko). The variety Kharkovskaya 55 was zoned in 1960 and was grown up at 28 regions. The biggest square was sowed by this variety in 1974, made 1616 thousand ha [1]. Thus, selection from populations resulted positive in accumulation and fixing even of such composite signs as winter hardiness and resistance to drowning therefore it was received winter rye varieties, valuable to production.

Hybridization between separate rye varieties, for the purpose of selection of the most productive and steady against drowning plants, was known from the first steps of rye breeding. For conducting crossings in large volumes at the Kharkiv breeding station in 1934 the technology of crossing, allowed to receive the significant amount of hybrid seeds with small expenses, was developed by G.M. Linnik. The academician V.Ya. Yuryev specified that at rye hybridization the intermediate forms in most cases are received [3]. So, the free intervarietal repollination between varieties Nemyshlyanskaya 953 and Kharkovskaya 194 led to the substantial increase of grain fineness at the local variety Nemyshlyanskaya 953, but the high-yield variety Kharkovskaya 194 reduced grain fineness and productivity [2].

Hybridization method in rye breeding at Institute for the first time was used by V.P. Pakhomova for the purpose of receiving a rye variety with a low and steady against drowning straw. Crossing was carried out by G.M. Linnik's method. As the parental component Petkus was short-stalked and insufficiently winterhardy therefore selection was made against the background of stiff conditions of the wintering. For this purpose the first generation of a hybrid was grown up in stiff conditions in winter period of the East of the country, and the next generations were grown up in southeast areas on the snowless slopes. Variety completion was carried out by the freezing of the plants, sowed in boxes by V.Ya. Yuryev's method. In 1960 this variety was transferred to the state strain testing named Kharkovskaya 60 (authors V.P. Pakhomova, S.A. Usan, B.M. Kononenko). Its acreage reached the maximal value in 1980 and was 1651 thous. ha [4].

Directions and results of researches at the period of 1964-1999. In 1967 the laboratory was headed by the candidate of agricultural sciences Hudoyerko Vladimir Ivanovich.

Within 13 years in rye breeding laboratory researches under the studying of breeding value of grain tetraploid rye were conducted. Researches were led by V.P. Pakhomova and A.A. Torop in 1962-1966, but V.I. Hudoyerko and L.V. Bondarenko in 1967-1975. Creation of a high-heterotic and heterogeneous tetraploid variety Kormovaya 51 (authors V.I. Hudoyerko, L. Bondarenko, I.A. Panchenko, B.A. Vesna), which was widely zoned since 1981 in Ukraine and abroad, became result of the work. Important reference features of a new variety were early ripeness, high fresh matter yield (up to 35,0 t/hectare) and seed productivity (up to 4,5 t/hectare) [5].

The creation of an essence new variety Kharkovskaya 78 in 1978 (authors V.I. Hudoyerko, I.A. Panchenko, L.V. Bondarenko, V.D. Kobylyansky, M.K. Kovalyov) became a new stage of winter rye breeding. It was the first short-stalked variety with a high resistance to drowning and completely suitable for intensive technologies of cultivation in Ukraine. Breeding on creation of the variety Kharkovskaya 78 was begun in 1970 by the technique, developed at Institute $[6,7,8]$. The opening new short-stalked forms in 1967 by the famous scientist-breeder V.D. Kobylyansky, which were a natural mutant of M-1 and genotypes created on a sample of Bulgarian rye (K-10028) and in which short-stalk caused by one gene [9], gave an impetus for the development of theoretical, methodical and practical prerequisites of winter rye hybrid breeding.

At Plant Production Institute nd. by V.Ya. Yuriev NAASit was planned the long-term program of receiving varieties-synthetics and hybrids on the basis of CMS and the donor of a selffertility, and the work on this program was begun. Further a genetic multiplicity of populations was studied, the initial material for population and heterotic breeding was created, winter rye varieties and hybrids were created, their seed farming was put and introduced to production.

As a result of work on the direction of varieties-synthetics breeding and varieties - populations by the team of laboratory was created the next varieties: Kharkovskaya 88 zoned since 1989 [10]; Kharkovskaya 95 zoned since 1995 and Kharkovskaya 98 zoned since 1998 [11]. The 
first variety-synthetic Kharkovskaya 88 contains five components with high general combining ability, allocated from the hybrid combinations, received with participation of dominant - shortstalked variety Kharkovskaya 60, Saratovskaya 4, Kharkovskaya 78 and Chulpan.

The variety-synthetic Kharkovskaya 95 contains six components with recessive polygenic short-stalk, allocated from hybrid combinations, in which family tree varieties Halo, Saratovskaya 5 and Merkator were participated.

Nine components with recessive polygenic short-stalk, selected from hybrid combinations, received with participation of varieties Kharkovskaya 95, SNG-181, Muro, Marder and Population 91-2 are a part of the variety-synthetic Kharkovskaya 98.

In 1999 it was created and transferred to the State strain testing the first in Ukraine and the UIS-countries winter rye hybrid Pervistok with potential yield of $10,0 \mathrm{t} \mathrm{he}^{-1}$ [12].

Directions and results of researches of the period 2000-2018. Since 1999 and up to now the laboratory was headed by the doctor of agricultural sciences, the senior researcher Yegorov Dmitriy Konstantinovich.

The laboratory of winter rye breeding and genetics continues researches on the direction of initial material creation for the heterotic breeding. For the last 18 years at the department a large number of varieties, hybrids, maternal and fatherly components of hybrids were created, the scientifically founded system of winter rye hybrids' seed farming were developed and introduced. In 2011 it was registered in NCPGRU the collection of 15 lines-maintaners of sterility, which is unique in Ukraine, and in 2016 - 2 samplers of lines-restorers of fertility.

In 2002 a new variety-synthetic Khasto, in which family tree were two high-heterotic populations, was entered in the Register of plant varieties of Ukraine. Variety Khasto had passed the formal examination and on it the state patent of Ukraine was got. Also this year (2002) the Ukrainian first hybrid Pervistok was registered and introduced to production.

In 2007 the winter rye variety-synthetic Khamarka, which contained in his family tree two composite high-heterotic population 86 - I and 89 - I, and the hybrid Yuryivets were entered in the Register of plant varieties suitable for distribution in Ukraine. The variety differed by the increased winter hardiness. The hybrid had high rates of grain quality, falling number $225-250 \mathrm{sec}$, and high potential yield of $10,5 \mathrm{tha}^{-1}$.

In 2008 the winter rye hybrid a Slobozhanets, which potential yield of $10 \mathrm{tha}^{-1}$,were entered in the Register of plant varieties suitable for distribution in Ukraine. The hybrid had high rates of processibility and grain quality, falling number 225-240 sec.

In 2011 the variety-population Pamyat Khudoyerka was entered in the Register of plant varieties suitable for distribution in Ukraine. The variety was created by individual selection of high-winterhardy plants from variety-population Kharkovskaya 98 with the subsequent negative selection. The variety has been the National standard of Ukraine since 2011.

In 2012 the variety-synthetic Stoir, created by polytopcross method, was entered in the Register of plant varieties suitable for distribution in Ukraine. Its family tree contained seven components, selected from hybrid combinations, received with participation of varieties and hybrids Esprit, Farino, Dino, LPH-28, LPH-29, Avanti and Kharkovskaya 98.

In 2015 producers was offered to use the Ukrainian first trilinear hybrid Harley with potential yield of $10 \mathrm{tha}^{-1}$. The hybrid has high rates of processibility and grain quality, falling number 225-240 sec.

In 2016 hybrids Jupiter and Saturn were entered in the Register of plant varieties suitable for distribution in Ukraine in a zone of the Steppe.

In 2015 maternal components of hybrids, which are simple hybrids, the Koroleva BK and Kharkovchanka BK, and lines of 961358 V, 120337 V, 932073 V were registered.

Varieties Kalipso, Clio, Ivanhoe, hybrids Neptune, Arey, and the line-restorer of fertility $063491 \mathrm{~V}$ pass the state variety testing now.

In 2016 at laboratory researches on definition of winter rye varieties` and hybrids 'possibility to use them for production of biogas were begun. It was proved that hybrids Saturn and Jupiter were able to form $50-70 \mathrm{t} \mathrm{ha}^{-1}$ of fresh matter, and were capable to provide production of biogas in number of $8830 \mathrm{~m}^{3} \mathrm{ha}^{-1}$. 
The leading scientists are authors of winter rye varieties and hybrids, created at laboratory for 110 years: Academician V.Ya. Yuryev, corresponding member I.M. Polyakov, doctors and candidates of science A.F. Gelmer, B.K. Enken, A.V. Chernyisheva, G.M. Linnik, N.I. Smirnitsky, M.V. Lyaskovskiy, V.P. Pakhomova, B.M. Kononenko, V.I. Hudoyerko, A.F. Zdrilko, G.K. Adamchuk, V.P. Derevyanko, I.A. Panchenko, L.V. Bondarenko, D.K. Yegorov, A.A. Zmievskaya $[13,14,15]$.

Introduction to production of the last varieties, created at laboratory, allows to get a harvest rise in $0,5-0,7 \mathrm{tha}^{-1}$, that makes $8-10$ million UAH a year in the conditions of Ukraine.

For the last 27 years the division works according to the European EUCARPIA program which includes more than 20 countries of Europe. Between participants exchange of an initial material and information about ecological tests of varieties and hybrids is conducted.

Conclusions. For the 110th existence of winter rye breeding and genetics laboratory at Institute Plant Production Institute nd. by V.Ya. Yuriev NAAS activity of collectives promoted to development of domestic winter rye breeding and to increasing of the state scientific capacity, that is confirmed by existence of weighable developments of theoretical and applied character.

\section{References}

1. Hudoerko VI, Bondarenko LV, Panchenko IA. Winter rye breeding. Selektsiya i semenovodstvo. 1979; 41: 33-36.

2. Yurev VYa, Pahomova VP. Seed farming of a rye Kharkovskaya 194. Selektsiya i semenovodstvo. 1949; 8: 49-52.

3. Yurev VYa. Isolation of a rye and influence of repollination on different varieties. Selektsiya i semenovodstvo. 1938; 11: 44-46.

4. Yegorov DK. Selection on field crops. Kharkiv: Magda LTD, 2008. P. 89-95.

5. Hudoerko VI. Winter rye. Kyiv: Urozhay, 1977. 96 p.

6. Hudoerko VI, Bondarenko LV, Panchenko IA. Winter rye breeding. Selektsiya i semenovodstvo. 1979; 41:33-36.

7. Hudoerko VI, Panchenko IA. Short-stem winter rye breeding. Selektsiya i semenovodstvo. 1977.; 35: 3-9.

8. Hudoerko VI, Panchenko IA. Methods of winter rye varieties breeding in East Forest-Steppe of Ukraine. Selektsiya i semenovodstvo. 1984; 57: 9-12.

9. Kobylyanskiy VD. The new source of short-stem for not laid down rye breeding. Vestnik selskokhoziaystvennoy nauki. 1971; 9: 85-62.

10. Hudoyerko VI, Panchenko IA, Gulaga VD, Velik II. Winter rye Kharkovskaya 88. Selektsiya I semenovodstvo. 1990; 4: 40.

11. Hudoyerko VI. Problem solution of the short-stem winter rye varieties creation in Ukraine. Naukovi osnovy stabilizatsii vyrobnytstva produktsii roslynnytstva. Proc. of the Conference. Kharkiv, 1999. P. 113-114.

12. Derevianko VP, Yehorov DK. Relevant issues of heterotic winter rye breeding. Kharkiv: MagdaLTD, 2008. $152 \mathrm{p}$.

13. Yuriev's school of plant breeders: ed. by VV Kyrychenko. Kharkiv: MagdaLTD, 2008. 252 p.

14. Scientists-geneticists, breeders and plant growers. In: Ukrainian scientists-landowners of XX st. Agrarna nauka. 2000; 4: 346.

15. Scientists-geneticists, breeders and plant growers. In: Ukrainian scientists-landowners of XX st. Agrarna nauka. 2003; 7: 503. 